\title{
Characterization of humic substances from five macrophyte species decomposed under different nutrient conditions
}

\author{
Bottino, F. 1,* ${ }^{*}$, Souza, B. P.2, Rocha, R. J. S.2, Cunha-Santino, M. B. ${ }^{2}$ and Bianchini Jr. I. ${ }^{2}$ \\ ${ }^{1}$ Instituto Federal de Educação, Ciência e Tecnologia de São Paulo, Campus Sorocaba. Rua Maria Cinto de \\ Biaggi, 130, bairro Santa Rosália. CEP: 18095-410. Sorocaba, SP, Brazil. \\ 2 Programa de Pós-Graduação em Ecologia e Recursos Naturais. Universidade Federal de São Carlos, Departa- \\ mento de Hidrobiologia. Rodovia Washington Luís, km 235, SP - 310. CEP: 13565-905. São Carlos, SP, Brazil. \\ * Corresponding author: flaviabottino@yahoo.com.br
}

Received: 28/01/20 Accepted: 30/06/20

\begin{abstract}
Characterization of humic substances from five macrophyte species decomposed under different nutrient conditions

Macrophyte detritus contribute up to $50 \%$ of carbon available for humic substances (HS) synthesis in aquatic ecosystems which influence the carbon supply for many ecological processes. This study reports on a qualitative characterization of the HS from five aquatic macrophytes species with different traits (free-floating: Eichhornia crassipes, Pistia stratiotes, and Salvinia auriculata; emerged: Sagittaria montevidensis; amphibian: Urochloa arrecta) decomposed under oligotrophic and eutrophic conditions. To do this, we performed a decomposition experiment using the litter bag technique in two tropical reservoirs (Rio de Janeiro State, Brazil). The nutrient and fiber content in the plant tissues used in the decomposition assays were analyzed. From the remaining detritus in the litter bags, the HS were extracted using analytical procedures based on their solubility in different $\mathrm{pH}$ ranges. The HS ratios were calculated considering the ratio of non-humified and humified materials (Humification Index - HI), the percentage of humic acid (HA) and the relationship between humic acid and fulvic acid (Polymerization Degree - PD). The amphibian and emerged species showed the highest cell wall content and the lowest and the highest C:N:P ratios, respectively. Eutrophication increased the HI values of all plant detritus. The detritus from the amphibian macrophyte showed the highest HA proportion (oligotrophic: $25.2 \%$; eutrophic: $21 \%$ ) and E. crassipes detritus the lowest HA yields (oligotrophic: $13 \%$; eutrophic: $11.4 \%$ ). The PD values were directly related to the HA percentage and the detritus from $E$. crassipes and $P$. stratiotes showed the lowest values. The C:N and C:P ratios and the macrophyte life form had minor importance in the HS genesis. The fiber content in the plant tissues predicted the HA yields and therefore the PD that increased in the eutrophic reservoir. The non-humic material was the main fraction of detritus in both reservoirs suggesting carbon accumulation mainly in the eutrophic reservoir with high macrophyte biomass.
\end{abstract}

Key words: aquatic ecosystems, DOC, eutrophication, humic acids, tropical reservoir

\section{RESUMO}

Caracterização das substâncias húmicas derivadas de cinco espécies de macrófitas decompostas em diferentes condições de trofia

Os detritos de macrófitas contribuem com até $50 \%$ do carbono disponivel para a sintese de substâncias húmicas (SH) em ecossistemas aquáticos, as quais influenciam o suprimento de carbono para muitos processos ecológicos. Este estudo descreve, por meio de razões especificas, a caracterização qualitativa das SH derivadas de cinco espécies de macrófitas aquáticas com diferentes características (livres-flutuantes: Eichhornia crassipes, Pistia stratiotes $e$ Salvinia auriculata; emersa: Sagittaria montevidensis; anfibia: Urochloa arrecta) sob decomposição em diferentes estados tróficos (oligotrófico e eutrófico). Experimentos de decomposição foram realizados usando-se a técnica dos litter bags em dois reservatórios tropicais (Rio de Janeiro, Brasil). O conteúdo de fibras e a concentração de nutrientes dos tecidos das plantas usadas nos ensaios de decomposição foram analisados. A partir dos detritos remanescentes nos litter bags, as SH foram extraidas por meio de procedimentos analíticos baseados na solubilidade das SH em diferentes classes de pH. Para caracterização das SH considerou-se a 
relação entre materiais não-humificados e humificados (Índice de Humificação-HI), a porcentagem de ácido húmico (HA) e a relação entre ácido húmico e ácido fúlvico (Grau de Polimerização-PD). As espécies anfíbia e emersa apresentaram maior conteúdo de fração celular, bem como menor e maior relação $C: N: P$, respectivamente. A eutrofização aumentou o HI dos detritos de todas as espécies de plantas. A macrófita anfibia apresentou a maior proporção de HA (oligotrófico: $25.2 \%$, eutrófico: $21 \%$ ) e E. crassipes os menores rendimentos de HA (oligotrófico: $13 \%$ e eutrófico: $11.4 \%$ ). Os valores de PD foram diretamente relacionados às porcentagens de HA e as espécies $\mathrm{E}$. crassipes $e \mathrm{P}$. stratiotes apresentaram os menores valores de PD. As relações C:N e C:P e a forma de vida das macrófitas não foram importantes para a formação de $S H$. $O$ conteúdo de fibras nos tecidos das plantas in fluenciou o rendimento de HA e, consequentemente, os valores de PD que aumentaram no reservatório eutrófico. O material não-húmico foi a principal fração dos detritos em ambos os reservatórios, sugerindo acúmulo de carbono, principalmente no reservatório eutrófico com maior biomassa de macrófitas.

Palavras chave: ácido húmico, COD, ecossistemas aquáticos, eutrofização, reservatório tropical

\section{INTRODUCTION}

In the Neotropics, macrophytes are an important organic matter source for aquatic ecosystems due to their species richness (Chambers et al., 2008). The organic matter derived from macrophytes encompasses about $80 \%$ of particulate organic matter (POM) and $20 \%$ of dissolved organic matter (DOM) (Uselman et al., 2012). In tropical freshwater ecosystems and in some wetlands, $50 \%$ of POM derived from macrophytes are particulate carbon (Particulate Organic Carbon - POC - in dry mass basis (Moran \& Hodson, 1989).

POC is the main precursor of the HS synthesis that comprises the rearrangement of carbon polymers due to biotic and abiotic factors (Piccolo et al., 2000) leading to the formation of humic acids (HA), fulvic acids (FA) and humin (HU). The HS yields are conditioned by environmental conditions, macrophyte traits (i.e. macrophyte life form) and POC chemical properties (e.g. fiber content in the plant tissue).

Temperature, oxygen and nutrients availability, $\mathrm{pH}$, influence the HS yields in aquatic ecosystems (Piccolo et al., 2000; Assunção et al., 2018). Eutrophication also induces the HS yields by increasing the immobilization (i.e. transformation of inorganic compounds into organics) or mineralization (carbon respiration) but both processes depend on the intrinsic characteristics of the macrophytes (Bottino et al., 2016).

The environmental conditions are directly related to the macrophyte traits and their structure (Pan et al., 2017; Schneider et al., 2018). The life form of macrophytes (e.g. emerged, submerged and free-floating) shows different constitutions of their tissues with different intrinsic characteristics (e.g. nutrient and fiber content) (Schneider et al., 2018). Emerged macrophyte species show higher HS yields than the free-floating ones due to their high fiber content, representing an important source of HS for tropical aquatic ecosystems (Assunção et al., 2016; Bottino et al., 2019). Moreover, low C:N:P ratios that indicates high detritus quality (Enriquez et al., 1993) are supposed to increase the decomposition since attends the microbial metabolism requirements (ecological stoichiometry) leading consequently to the exposure of fibers (Assunção et al., 2018).

HS transformations into HA and/or FA are concurrent processes and are related to the POC chemical properties (e.g. molecular weight, concentration of dissolved carbon and nutrients in the plant tissues) that determine their biodegradability and consequently their fate and role in aquatic ecosystems (Scofield et al., 2015). The main fraction of HS in aquatic ecosystems is the FA that are more bioavailable than HA, exhibiting low molecular weight and aliphatic structure (Schellekens et al., 2017). The formation of HA is a long-term process due to their high aromaticity and low solubility. Both HA and FA were considered macromolecules responsible for carbon accumulation in ecosystems. However, a range of studies show these molecules are organic resources susceptible to microbial respiration contributing to the organic pool in aquatic ecosystems (Tranvik, 1998; Farjalla et al., 2009; Schellekens et al., 2017; Assunção et al., 2018). In contrast, $\mathrm{HU}$ is an insoluble material not considered as HS and it is stored within the 
sediments due to its low biodegradability (Olk et al., 2019).

Understanding the different types of carbon sources (HA, FA and HU) in a range of environments and their origin (macrophyte traits and trophic status) is important to predict the carbon cycling and energy flow in aquatic ecosystems mainly in humic-rich systems that are usually nutrient limited. In the tropics, it has particular importance since freshwater environments are intensively colonized by different macrophyte species and the decomposition has predominant conditions to be faster than in the temperate ecosystems.

Our study aimed to analyze how the life strategy of macrophytes and the trophic status of aquatic ecosystems influence the formation of HS during the aquatic decomposition. We hypothesize high nutrient concentration in the eutrophic reservoir will enhance the decomposition of macrophytes, and thus increase the humication of organic matter and reduce the accumulation of POC in the sediments that is expected to increase in oligotrophic systems.

\section{MATERIAL AND METHODS}

\section{Sampling site description}

Macrophyte sampling and decomposition experiments were carried out in two tropical reservoirs in Rio de Janeiro State (Brazil). The Lajes Reservoir ( $22^{\circ} 42^{\prime} 02^{\prime \prime} \mathrm{S}$; $\left.43^{\circ} 52^{\prime} 54^{\prime \prime} \mathrm{W}\right)$ is an oligo-mesotrophic ecosystem, which has a hydraulic retention time of 287 days, and water column transparency of about $5.5 \mathrm{~m}$. The Vigário Reservoir $\left(22^{\circ} 40^{\prime} 18^{\prime \prime} \mathrm{S}\right.$; $\left.43^{\circ} 52^{\prime} 78^{\prime \prime} \mathrm{W}\right)$ is a eutrophic system with 30 days of hydraulic retention time and $1.0 \mathrm{~m}$ of water column transparency (Rocha, 2012). Both reservoirs have warm and rainy summers and dry winters (Aw according to Köppen classification) with a mean annual air temperature ranging from 17 to $24^{\circ} \mathrm{C}$. The physical and chemical limnological variables of the water column were similar for water temperature, dissolved oxygen (DO) in both reservoirs, but electrical conductivity and phosphorus concentrations were higher in the Vigário than in the

Table 1. Limnological variables (mean \pm standard deviation)** measured during the decomposition experiment in Vigário and Lajes Reservoirs. $\mathrm{T}=$ water temperature; $\mathrm{DO}=$ dissolved oxygen; $\mathrm{ORP}=$ oxi-reduction potential; $\mathrm{CE}=$ electrical conductivity; $\mathrm{TP}=$ total phosphorus; $\mathrm{SRP}=$ soluble reactive phosphorus; $\mathrm{NO}_{2}{ }^{-}=$nitrite; $\mathrm{NO}_{3}{ }^{-}=$nitrate; $\mathrm{Z}_{\mathrm{SD}}=$ Secchi Disc Depth. *Not detectable. ${ }^{* *}$ Data obtained from Rocha, 2012. Variáveis Limnológicas (média \pm desvio padrão)** medidas durante o experimento de decomposição os reservatórios Lajes e Vigário. $T=$ temperatura da água; $D O=$ oxigênio dissolvido; ORP: potencial de oxi-redução; $C E=$ condutividade elétrica; $T P=$ fósforo total; $S R P=$ fósforo solúvel reativo; $\mathrm{NO}_{2}^{-}=$nitrito; $\mathrm{NO}_{3}^{-}=$nitrato. $Z_{S D}=$ Profundidade do Disco de Secchi. * Não detectado. ** Dados obtidos de Rocha, 2012.

\begin{tabular}{ccc}
\hline Variable & $\begin{array}{c}\text { Lajes Reservoir } \\
\text { (Oligotrophic) }\end{array}$ & $\begin{array}{c}\text { Vigário Reservoir } \\
\text { (Eutrophic) }\end{array}$ \\
\hline $\mathrm{T}\left({ }^{\circ} \mathrm{C}\right)$ & $23.84 \pm 1.98$ & $23.22 \pm 1.74$ \\
$\mathrm{DO}(\mathrm{mg} / \mathrm{L})$ & $7.74 \pm 0.7$ & $7.11 \pm 0.88$ \\
$\mathrm{pH}$ & $7.87 \pm 0.18$ & $6.84 \pm 0.12$ \\
$\mathrm{ORP}(\mathrm{mV})$ & $169.91 \pm 45.8$ & $159.43 \pm 37.01$ \\
$\mathrm{CE}(\mu \mathrm{S} / \mathrm{cm})$ & $30.66 \pm 1.43$ & $75.83 \pm 6.87$ \\
$\mathrm{TP}(\mu \mathrm{g} / \mathrm{L})$ & $4.72 \pm 1.97$ & $59.97 \pm 23.43$ \\
$\mathrm{SRP}(\mu \mathrm{g} / \mathrm{L})$ & $2.32 \pm 0.42$ & $30.1 \pm 5.18$ \\
$\mathrm{NO}_{2}{ }^{-}(\mathrm{mg} / \mathrm{L})$ & $*$ & $0.083 \pm 0.031$ \\
$\mathrm{NO}_{3}{ }^{-}(\mathrm{mg} / \mathrm{L})$ & $0.42 \pm 0.43$ & $5.82 \pm 1.26$ \\
$\mathrm{Z}_{\mathrm{SD}}(\mathrm{m})$ & $3.78 \pm 0.32$ & $0.77 \pm 0.35$ \\
\hline
\end{tabular}


Lajes Reservoir. However, the $\mathrm{pH}$ values were higher in the Lajes than in the Vigário Reservoir (Table 1).

\section{Decomposition of macrophytes and POC obtention}

Four macrophyte species were collected from the coastal regions of Vigário Reservoir (Eichhornia crassipes (Mart.) Solms., Pistia stratiotes (L.), Sagittaria montevidensis (Cham. \& Schltdl.) Kuntze and Urochloa arrecta (Hack. \& Schinz) Morrone \& Zuloaga). Salvinia auriculata (Aubl.) was collected from the Lajes Reservoir where only this one species was found. E. crassipes, $P$. stratiotes and $S$. auriculata are free-floating species, $S$. montevidensis and $U$. arrecta are emerged and amphibian species, respectively.

The plants were washed to remove the attached coarse material and dried $\left(50^{\circ} \mathrm{C}\right)$ to constant mass. The decomposition experiment was carried out in litter bags $(20 \times 35 \mathrm{~cm} ; 0.2 \mathrm{~mm}$ mesh size) with approximately $20 \mathrm{~g}$ of the dried plant material of each plant species $(n=300)$. The litter bags were incubated (depth: $2.5 \mathrm{~m}$ ) for 120 days in the Lajes $(n=150)$ and in Vigário reservoirs $(n=150)$. Three litter bags of each macrophyte species were removed randomly from the water column in 10 sampling occasions $(1,3,5$, $10,15,20,30,60,90$ and 120 days). The remaining detritus in each litter bag (considered as remaining POM) were dried $\left(50^{\circ} \mathrm{C}\right)$ to constant mass, weighed, triturated and stored in polypropylene bags.

\section{Chemical composition of the macrophytes}

The initial macrophyte tissue content of nitrogen (N) and phosphorus (P) were analyzed according to Allen et al., (1974) and Rocha et al., (2014), respectively. Measurements of carbon (C) content in the plant tissues were performed by the calcination method $\left(550^{\circ} \mathrm{C} ; 2 \mathrm{~h}\right)$ (Wetzel \& Likens, 1990). From the nutrient and carbon contents in the macrophyte tissues, the proportions of $\mathrm{C}: \mathrm{N}$, $\mathrm{C}: \mathrm{P}$ and $\mathrm{N}: \mathrm{P}$ were calculated in terms of mass ratio. The initial content of lignin was determined using the gravimetric method after acid digestion (Allen et al., 1974) and the cell wall fraction was measured using the neutral detergent method (Van Soest \&Wine, 1967). According to the neutral detergent method, the cell wall fraction is the association of fibers (hemicellulose, cellulose and lignin), including ashes and some degraded proteins (Van Soest \& Wine, 1967).

\section{Humic Substance extraction}

The HS extraction was performed on $1.0 \mathrm{~g}$ of the POC (dry mass) using $\mathrm{NaOH}(0.5 \mathrm{~mol} / \mathrm{L})$ and analytical procedures based on their solubility in different $\mathrm{pH}$ ranges (Hayes \& Swift, 1978; Hayes et al., 2010). The alkaline samples were stirred ( $1 \mathrm{~h}$ per day), centrifuged ( $2740 \mathrm{~g}$ for $25 \mathrm{~min}$ ) and the soluble material was filtered $(\Phi=0.45 \mu \mathrm{m})$. This procedure was repeated over time until absorbance $<0.1(\lambda: 450 \mathrm{~nm})$ (Ultrospec 2100 Pro, Sweden). HS were fractioned into HA and FA by lowering the $\mathrm{pH}$ to $\approx 1.0(\mathrm{HCl} 2 \mathrm{~N})$ and then were centrifuged ( $2740 \mathrm{~g}$ for $25 \mathrm{~min})$. The $\mathrm{pH}$ of the HA and FA solutions was adjusted to 5.0 and 8.0 , respectively. The remaining material that was not extracted by alkali was considered HU (non humic material). The total organic carbon (TOC) concentration in the dissolved samples of HA, FA and HU was measured using a carbon analyzer (TOC-L CPH, Shimadzu, Japan).

\section{Qualitative Measurements of HS (HS ratios)}

The Humification Index (HI) was calculated according to Dudal \& Roy (1993) (Equation 1). The HA percentage (Equation 2) was proposed by Senesi (1989) and Polimerization Degree (PD) was calculated according to Equation 3 (Senesi, 1989; Iqdal et al., 2010):

$$
\begin{aligned}
& H I=\frac{N H}{(F A+H A)} \\
& H A(\%)=\frac{H A}{(F A+H A)} \times 100 \\
& P D=\frac{H A}{F A}
\end{aligned}
$$


where:

$\mathrm{NH}=$ Non-Humic Material (i.e. $\mathrm{HU}$ );

$\mathrm{HA}=$ Humic Acid;

$\mathrm{FA}=$ Fulvic Acid.

The remaining mass in the litter bags (remaining POM - dry mass) was used to represent the relationship between the decomposition and the HS synthesis (indicated by HI values).

\section{Statistical analysis}

After the log transformations, the data fulfilled the normality and homoscedasticity assumptions. The comparisons of the ratios in different nutrient conditions and among the plants were performed using the repeated measures ANOVA and Tukey post-hoc tests. We also performed linear regressions to compare the HS ratios between oligotrophic and eutrophic conditions. The statistical significance was set as 0.05 . The analyses were performed using Statistica 7.

\section{RESULTS}

\section{Macrophyte Traits}

The carbon (C) content in the free-floating plant tissues ranged from $37 \%$ to $44 \%$. In the emerged and amphibian species, the $\mathrm{C}$ content was $46 \%$ and $45 \%$, respectively. The highest
$\mathrm{C}: \mathrm{N}$ and $\mathrm{C}: \mathrm{P}$ ratios were accounted for by the amphibian macrophyte and the lowest for the emerged plant. Amphibian species also showed the highest lignin and cell wall fraction and the lowest values were recorded for the free-floating P. stratiotes (Table 2).

The free-floating species showed the highest HI values ( $P$. stratiotes - maximum: 5.1 by day $120)$ and the lowest values (E. crassipes and $S$. auriculata - maximum: 2.62 and 1.33 , respectively). There were significant differences in the temporal variation of $\mathrm{HI}$ formation for each macrophyte species $(p<0.01)$. For HA and PD, the amphibian species showed the highest values (maximum: 25.25 for HA and 0.33 for PD) and the free-floating $E$. crassipes the lowest (maximum: 12.21 for HA and 0.14 for PD). The lowest $\mathrm{PD}$ values showed a gradient among the detritus derived from free-floating species (E. crassipes $<$ $P$. stratiotes $<S$. auriculata). The HA ranged significantly over time for all macrophyte species $(p<0.01)$.

\section{Reservoir nutrient conditions}

The HI values were higher in the eutrophic reservoir than in the oligotrophic ecosystem for all the plants (Fig. 1) with significant differences $(p=0.03)$. In general, the HI increased for all the plant species from day 20 in both oligotrophic and eutrophic environments. Comparing both reservoirs, E. crassipes showed the highest varia-

Table 2. Tissue contents of five macrophyte species (Mean \pm SD). C: initial carbon content; P: initial phosphorus content; L: Lignin initial content; $\mathrm{C}: \mathrm{N}, \mathrm{C}: \mathrm{P}$ and $\mathrm{N}: \mathrm{P}$ - ratios (on percentage basis); CWF: cell wall fraction; SD: Standard Deviation. Conteúdo do tecido de 5 espécies de macófitas (média \pm Desvio Padrão). C: conteúdo inicial de carbono; P: conteúdo inicial de fósforo; L: conteúdo inicial de lignina; relações C:N, C:P e N:P (em porcentagem); CWF: fração da parede celular; SD: Desvio Padrão.

\begin{tabular}{|c|c|c|c|c|c|}
\hline \multirow{3}{*}{ Variable } & \multicolumn{4}{|c|}{ Plant Species and Life form } & \multirow{3}{*}{$\begin{array}{r}\text { Amphibian } \\
U . \text { arrecta } \\
\end{array}$} \\
\hline & \multicolumn{3}{|c|}{ Free-floating } & \multirow{2}{*}{$\begin{array}{l}\text { Emerged } \\
\text { S. montevidensis }\end{array}$} & \\
\hline & E. crassipes & P. stratiotes & S. auriculata & & \\
\hline $\mathrm{C}(\%)$ & $37.3 \pm 0.6$ & $41.8 \pm 0.2$ & $44.0 \pm 0.6$ & $45.8 \pm 0.7$ & $45.0 \pm 0.4$ \\
\hline $\mathrm{C}: \mathrm{N}$ & 24.8 & 24.1 & 33.1 & 21.8 & 49.6 \\
\hline $\mathrm{C}: \mathrm{P}$ & 382.8 & 315.2 & 819.9 & 140.1 & 1085 \\
\hline $\mathrm{N}: \mathrm{P}$ & 15.5 & 13.1 & 24.8 & 6.4 & 22 \\
\hline L $(\%)$ & $35.0 \pm 6.0$ & $28.6 \pm 1.2$ & $49.0 \pm 1.3$ & $44.8 \pm 2.5$ & $52.3 \pm 1.9$ \\
\hline CWF $(\%)$ & $46.3 \pm 5.8$ & $56.0 \pm 7.1$ & $56.9 \pm 2.9$ & $62.8 \pm 1.9$ & $80.4 \pm 2.9$ \\
\hline
\end{tabular}



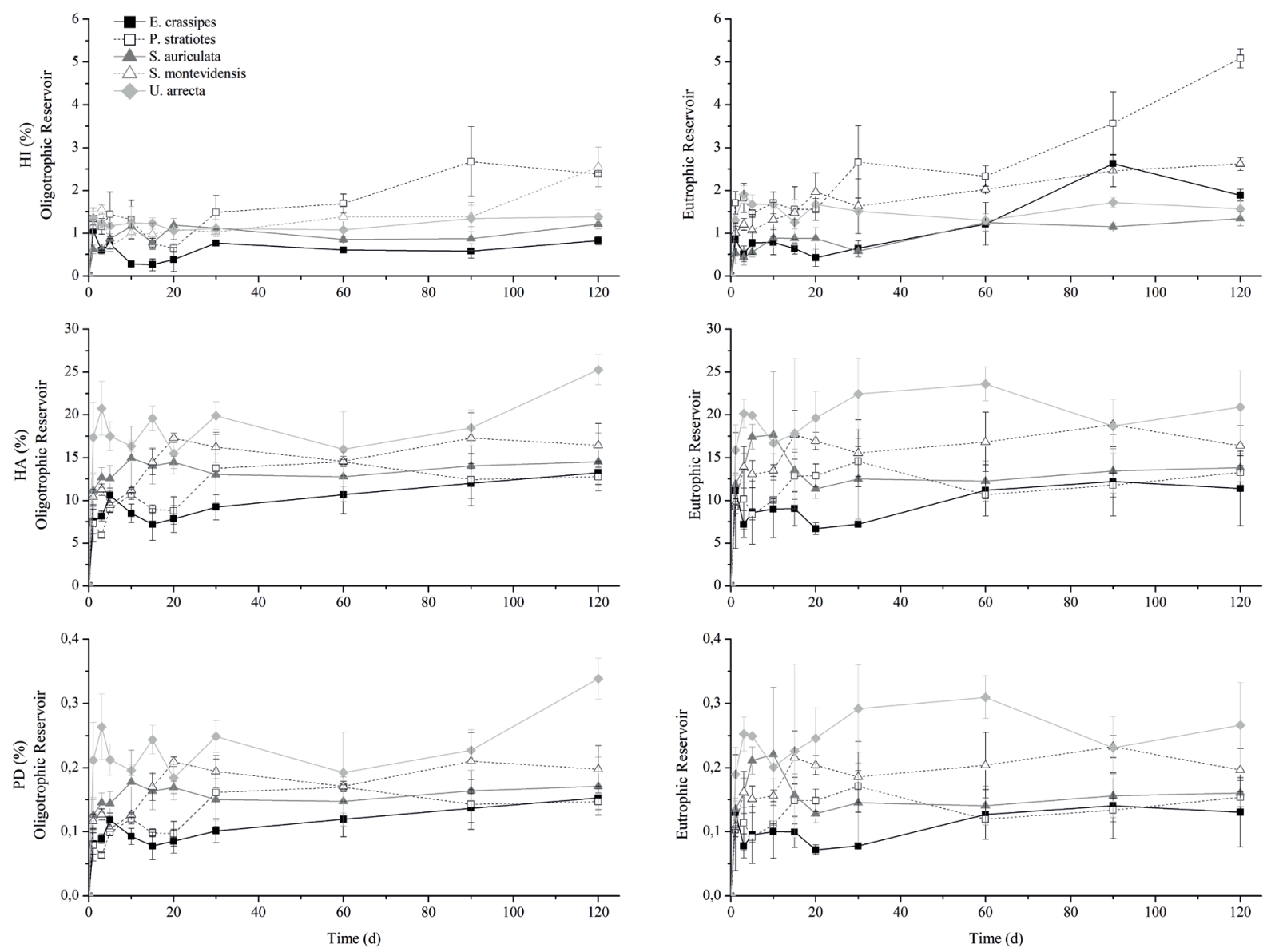

Figure 1. Temporal variation of Humification Index (HI), Acid Humic Percentage (HA) and Polymerization Degree (PD) of five macrophyte species from oligotrophic and eutrophic reservoirs. The vertical bars are standard deviation. Free-floating species: E. crassipes, P. stratiotes and S. auriculata; Emerged species: S. montevidensis; Amphibian: U. arrecta. Variação Temporal do Índice de Humificação (HI), Porcentagem de Ácido Húmico (HA) e Grau de Polimerização (PD) de cinco espécies de macrófitas derivadas de reservatório oligotrófico e eutrófico. As barras verticais indicam o desvio padrão da média. Espécies livres flutuantes: E. crassipes, P. stratiotes e S. auriculata; Espécie emersa: S. montevidensis; Espécie Anfíbia: U. arrecta.

tion of HI mainly from day 60 (0.6 and 1.21 in oligotrophic and eutrophic conditions, respectively). For the amphibian species, the variation between both reservoirs was lower than for other species (Fig.1).

Comparing the plants species in both environments, the HI values were similar, except for $P$. stratiotes, which was different from $E$. crassipes ( $p=0.001$ for both environments), and from $S$. auriculata ( $p=0.03$ in the oligotrophic and $p=0.01$ in the eutrophic reservoir). The HI values were 4.5 times higher for E. crassipes and 2.2 times higher for $P$. stratiotes in the eutrophic environ- ment. Considering all the plants, in the eutrophic reservoir, the $\mathrm{HI}$ values were $30 \%$ higher than in the oligotrophic reservoir $\left(\mathrm{t}=0.4, \mathrm{r}^{2}=0.65\right.$, $p<0.001$ ).

In general, the pattern of temporal variation of the HA percentage was similar in both environments with the highest values from day 60 . However, there were significant differences between both reservoirs ( $p=0.008$; Table 3 ) and eutrophic reservoir showed the highest HA. The maximum HA yield from $U$. arrecta was $25.2 \%$ in the oligotrophic and $21 \%$ in the eutrophic conditions on day 120 of incubation. For E. crassipes, the maximum 
Table 3. Statistical parameters (SS: Sum of Squares, F and $p$ values) derived from the ANOVA Repeated Measures analyses of Humification Index, Humic Acids and Polymerization Degree of different plant species. Statistical significance was set at $5 \%$. TS: Trophic statuses (oligotrophic and eutrophic), MS: Macrophyte Species, T: Time. Parâmetros estatísticos (SS: Soma dos quadrados, valores de F e p) derivados da ANOVA de Medidas Repetidas para o índice de Humificação, Ácidos Húmicos e Grau de Polimerização das diferentes espécies de plantas. A significância estatística foi estabelecida em $5 \%$. TS: Estado Trófico (oligotrófico e eutrófico); MS: Espécies de Macrófitas; T: Tempo.

\begin{tabular}{|c|c|c|c|c|}
\hline Variable & Anova Effect & SS & $\mathbf{F}$ & $p$ \\
\hline \multirow{7}{*}{ HI } & TS & 16 & 10.64 & 0.003 \\
\hline & MS & 625 & 104 & 0.00001 \\
\hline & $\mathbf{T}$ & 39.7 & 3 & 0.002 \\
\hline & TS*MS & 34 & 6 & 0.003 \\
\hline & $\mathrm{TS} * \mathrm{~T}$ & 49.5 & 4 & 0.0002 \\
\hline & MS*T & 155 & 3 & 0.00002 \\
\hline & TS*MS*T & 107 & 2 & 0.001 \\
\hline \multirow{7}{*}{ HA } & TS & 385 & 24 & 0.008 \\
\hline & MS & 435 & 37 & 0.0001 \\
\hline & $\mathbf{T}$ & 1140 & 4.2 & 0.0005 \\
\hline & TS*MS & 1380 & 22 & 0.00001 \\
\hline & $\mathbf{T S} \mathbf{T}$ & 940 & 3.5 & 0.0005 \\
\hline & MS*T & 300 & 2.7 & 0.000005 \\
\hline & TS*MS*T & 1587 & 1.47 & 0.05 \\
\hline \multirow{7}{*}{ PD } & TS & 0.7 & 7.8 & 0.01 \\
\hline & MS & 0.64 & 164 & 0.00001 \\
\hline & $\mathbf{T}$ & 0.9 & 7.6 & 0.00001 \\
\hline & TS*MS & 0.34 & 0.88 & 0.48 \\
\hline & $\mathbf{T S} * \mathbf{T}$ & 0.1 & 0.87 & 0.55 \\
\hline & MS*T & 0.12 & 3.0 & 0.0002 \\
\hline & TS*MS*T & 0.7 & 1.48 & 0.07 \\
\hline
\end{tabular}

yields of HA were $13 \%$ in the oligotrophic and $11.4 \%$ in the eutrophic system on day 120 . The comparison of the HA percentages showed differences only between $U$. arrecta and other species in the oligotrophic reservoir. In the eutrophic environment we only found differences between $U$. arrecta and E. crassipes and P. stratiotes.

The PD values (Fig. 1) showed significant differences in both the nutrient condition $(p=0.01$, except for $P$. stratiotes and $S$. auriculata, $p=0.03$ ). The $U$. arrecta detritus showed the highest values ranging from 0.18 to 0.33 in the oligotrophic and from 0.19 to 0.31 in the eutrophic reservoirs. $E$. crassipes had the lowest PD values, ranging from $0.08-0.15$ in the oligotrophic and from 0.07 to 0.14 in the eutrophic reservoirs. The significant differences in the oligotrophic system occurred between $U$. arrecta and the other plants $(p=0.017$ for the interactions with $E$. crassipes and $P$. stratiotes; $p=0.01$ for the interaction with $S$. auriculata and $S$. montevidensis). In the eutrophic reservoir, the plant detritus was significantly different $(p<0.01$ for all the macrophytes and for $P$. stratiotes and $S$. auriculata, $p=0.03$ ), except for $E$. crassipes and $P$. stratiotes and $S$. montevidensis and $S$. auriculata (Table 3 ). There was a positive relationship between PD values in the oligotrophic and in the eutrophic reservoirs $\left(\mathrm{t}=36.7 ; \mathrm{r}^{2}=0.8 ; p<0.01\right)$ indicating that polymerization was faster in the eutrophic reservoir (ca. $4 \%$ ).

The results suggest that, regardless of the condition of the nutrient, the detritus with the lowest remaining mass (POM after 120 days of 


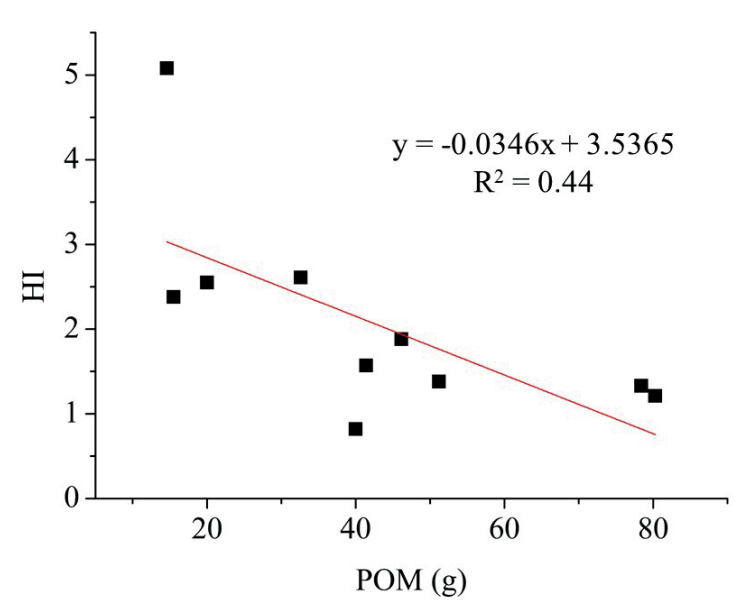

Figure 2. Relationship between remaining POC and HI for all macrophyte species in both reservoirs. Relação entre COP remanescente e HI para todas as espécies de macrófitas em ambos os reservatórios.

decomposition) has the highest HI values (Fig. 2), that is, the recalcitrant remaining material is processed slowly and tends to increase the accumulation of non-humic material (HU) in these reservoirs. It is important to consider that the $\mathrm{HI}$ is qualitative, and therefore does not reflect the total remaining mass.

\section{DISCUSSION}

HS play an important role in aquatic ecosystems (e.g. binding pollutants, influencing biogeochemical processes, affecting light availability in the water column and microbial respiration) (Steinberg et al., 2006; Olk et al., 2019). For aquatic HS derived from macrophytes detritus, the plant traits (life form, nutrient and fiber contents) and the limnological characteristics growing environment of the plants influence the detritus processing (Li et al., 2013). The microbial activity on the detritus causes the temporal variation of the relationship between humic and non humic materials (Olk et al., 2019). In general, non-humic material increase over time (high HI values), decreasing the HS yields indicating that the main fate of POM is the accumulation in the aquatic ecosystems. Therefore, we reject the hypothesis that eutrophic status would enhance the humification of organic matter.
The nutrient content in the macrophyte tissues predicts the detritus nutrient quality and is considered a major driver of the decomposition (Li et al., 2012). Detritus with low carbon and high $\mathrm{N}$ and $\mathrm{P}$ contents, and consequently low $\mathrm{C}: \mathrm{N}$ and $\mathrm{C}: \mathrm{P}$ ratios, respectively are supposed to have high detritus quality and improve the action of biota on detritus processing (Enríquez et al., 1993; Li et al., 2012). Low C:N and C:P ratios of floating species and low fiber content such as $E$. crassipes and $P$. stratiotes, receptively supported plant detritus processing during the decomposition decreasing the carbon available to HS synthesis. We suppose that $P$. stratiotes detritus is highly leachable (Bianchini Jr. et al., 2010) and the remaining POC shows low degradability increasing its potential of accumulation.

On the other hand, the free-floating $S$. auriculata, showed low detritus quality and high fiber content. Floating plants growing in oligotrophic environment show low detritus quality suggesting a high rate of nutrient reabsorption in plants growing in a poor nutrient condition (Rejmanková \& Houdková, 2006) indicating that the nutrient condition of the reservoir influences the detritus C:N:P ratio. Moreover, Salvinia sp. detritus are recalcitrant and have a high potential of HA formation (Assunção et al., 2017). Therefore, considering the free-floating macrophytes, the SH synthesis prevailed over non-humic material formation for high quality detritus (E. crassipes) and high fiber content detritus ( $S$. auriculata) indicating that macrophyte traits are important for POC transformations within aquatic ecosystems.

Recent studies (Assunção et al., 2018; Bottino et al., 2019) showed that the decomposition of floating macrophytes yielded from $60 \%$ to $89 \%$ of POC that was converted into HS generating $0.9-1.1 \%$ of HA and $1.0-7.5 \%$ of FA. For emerged species, the detritus corresponded to $75-92 \%$ of POC yielding up to $5 \%$ of HA and $30 \%$ of FA. Therefore, the main fraction generated from POC decay is the non humic material (HU in this study). HU is considered a refractory compound with high molecular weight formed by lipoprotein, waxes, long-chain fatty acids that decrease its potential of reaction, and consequently is accumulated in the sediments (Chang et al., 2014; Zhang et al., 2015). The recalcitrance of 
some compounds is due to the different carbon types that can act as an electron donor in the long-term in specific conditions of dissolved oxygen availability, $\mathrm{pH}$, electrical conductivity and microorganism's metabolic diversity (Zhang et al., 2015, Roden et al., 2010; Liu et al., 2017).

In this study, we consider $\mathrm{HU}$ as a fraction that is not operationally obtained using the extraction methods in different $\mathrm{pH}$ ranges. However, this fraction may be susceptible to abiotic and biotic transformations in the long-term (for example, the complete HS synthesis depends on the exposition of the fibers, which is a long-term process). Therefore, the HU prevalence over HS may be due to the high recalcitrant content in the tissues of the plants (cellulose and lignin, for example) that are processed over time due to the enzyme activity of specific organisms. Many aspects influence the microbial enzymatic activity, for example, some polymers such as lignin is tightly packed than cellulose and hemicellulose are and therefore it is decomposed in the long term (Pérez et al., 2001). The highest $\mathrm{HI}$ in eutrophic (higher HU than HS formation) is probably due to the fastest decomposition rates in nutrient-rich environments (Gullis et al., 2006) that increase the amounts of secondary metabolites in the detritus possibly affecting the humus formation.

The main fraction of HS is the FA due to its low aromaticity and low molecular weight. However, the FA conversion into microbial biomass or $\mathrm{CO}_{2}$ (immobilization and mineralization, respectively) is a high-speed process in aquatic ecosystems, suggesting that FA act as a terminal electron acceptor (Klüpfel et al., 2014; Bottino et al., 2019). In general, the HA percentage increased over time in both environments for all the plant species indicating the availability of precursors of HA (exchange between HA and FA for example; Thurmann, 1985).

The structural compounds were the main driver of HA formation. In general, the amphibian macrophyte showed the highest $\mathrm{C}: \mathrm{N}: \mathrm{P}$ ratio and the highest lignin content and cell wall fraction contributing to the formation of HA suggesting the plant traits were important to HS $(\mathrm{HA}+\mathrm{FA})$ yields. The highest PD values reinforces the statement that $U$. arrecta is the main species contributing to the carbon cycling through the HA formation. In absolute terms, in the Lajes reservoir the emerged species supported the HS synthesis and in relative terms, the oligotrophic condition improved the HA formation from $U$. arrecta detritus. Therefore, the low nutrient availability contributed to the HA as the main carbon source in the ecosystem. The decay of the autochthonous carbon sources produces a stable type of carbon, i.e. HA that comprise one route of carbon cycling in freshwater systems. Considering that $U$. arrecta is an invasive species in Brazil, it is important to know how its refractory carbon impacts the carbon cycle within tropical reservoirs.

Our results showed that the HS genesis depends on macrophyte traits (life form, C:N:P ratio and fiber content) in different ways. While life forms of the macrophytes had a minor importance to the humification there was not a clear pattern for the $\mathrm{C}: \mathrm{N}: \mathrm{P}$ ratio role. However, the fibers predicted a slow route of less bioavailable compound synthesis (HA yields) with molecules and a high chemical complexity (high PD) mainly for amphibian species. The eutrophication increased the non-humic material that may be stored within the sediments and contribute to the diagenetic processes. However, in a nutrient rich reservoir, the HA genesis increased along with the PD (free-floating < emerged < amphibian) indicating the HS in this ecosystem is less available for heterotrophic respiration. In the oligotrophic reservoir, the non-humic fraction also prevailed but the HA formation was slightly slow over time. Overall, the remaining detritus mass from decomposition seems to influence the HS synthesis but further studies should address the quantitative aspects of this relationship.

\section{ACKNOWLEDGEMENTS}

The authors would like to thank the Fundação de Amparo à Pesquisa do Estado de São Paulo FAPESP (Process number: 2012/21829-0) and P\&D ANAEEL/Light Energia S.A. (Process number: 5161-005/2010) for their financial support and to the Coordenação de Aperfeiçoamento de Pessoal de Nível Superior - CAPES for the scholarship awarded to the second and third authors. The authors also thank the contribution of 
Kevin Murphy (University of Glasgow, UK) who revised the English language in this manuscript.

\section{REFERENCES}

ALLEN, S. E., H. M. GRIMSHAW, J. PARKINSON \& C. AQUARMBY. 1974. Chemical analysis of ecological materials. Blackweell Publising. Oxford.

ASSUNÇÃO, A. A. W., B. P. SOUZA, M. B., SILVA, W. T. L.; CUNHA-SANTINO \& I. BIANCHINI Jr. 2017. Molecular changes of aquatic humic substances fromed from four aquatic macrophytes under different nutrient condition. Chemistry and Ecology, 33: 918-931.

ASSUNÇÃO, A. A. W., B. P. SOUZA, M. B. CUNHA-SANTINO \& I. BIANCHINI Jr. 2018. Formation and mineralization kinetics of dissolved humic substances from aquatic macrophyte decomposition. Journal of Soils and Sediments, 18:1252-1264. DOI: 10.1007/ s11368-016-1519-x

BIANCHINI JR., I., R. H. SILVA, M. B. CUNHA-SANTINO \& R. S. PANHOTA. 2010. Aerobic and anaerobic decomposition of Pistia stratiotes leachates from a tropical eutrophic reservoir (Barra Bonita, SP, Brazil). Brazilian Journal of Biology, 70: 559-568.

BOTTINO, F., M. B. CUNHA-SANTINO \& I. BIANCHINI Jr. 2016. Decomposition of particulate organic carbon from aquatic macrophytes under different nutrient conditions. Aquatic Geochemistry, 22: 1-17. DOI: 10.1007/s10498-015-9275-X

BOTTINO, F., M. B. CUNHA-SANTINO \& I. BIANCHINI Jr. 2019. Kinetic aspects of humic substances derived from macrophyte detritus decomposition under different nutrient conditions. Environmental Science and Pollution Research, 26: 15931-15942. DOI: 10.1007/s11356-019-04882-z

CHAMBERS P. A., P. LACOUL, K. J. MURPHY \& S. M. THOMAZ. 2008. Global diversity of aquatic macrophytes in freshwater. Hydrobiology, 595: 9-26.

CHANG R. R., M. H. B. MYLOTTE, R. HAYES, R. MCLNERNEY \& Y. M. TZOU. 2014. A comparison of the compositional differences between humic fractions isolated by the IHSS and exhaustive extraction procedures. Naturwissenschaften, 101: 197-209. DOI: $10.1007 / \mathrm{s} 00114-013-1140-4$

DUDAL, R. \& R. N. ROY. 1993. Integrated plant nutrition systems. Report of an expert consultation. FAO - Food and Agriculture Organization of the United Nations. Available at: http://www.fao.org/library/library-home/en/. Acessed January, 2017.

ENRÍQUEZ, S., C. M. DUARTE \& K. SAND-JENSEN. 1993. Patterns in decomposition rates among photosynthetic organisms: the importance of detritus $\mathrm{C}: \mathrm{N}: \mathrm{P}$ content. Oecologia, 94: 457-471.

FARJALLA, V. F., A. M., AMADO, A. L. SUHETT \& F. MEIRELLES-PEREIRA. 2009. DOC removal paradigms in highly humic aquatic ecosystems. Environmental Science and Pollution Research, 16:531-538. GULLIS, V., V. FERREIRA \& M. A. S. GRAÇA. 2006. Simulation of leaf litter decomposition and associated fungi and invertebrates by moderated eutrophication: implications for stream assessment. Freshwater Biology, 51: 1655-1669. DOI: 10.1111/j. 1365-2427.2006.01615.x

HANSEN, A. M., T. E.C. KRAUS, B. A. PELLERIN, J. A. FLECK, B. D. DOWNING \& B. A. BERGAMASCHI. 2016. Optical properties of dissolved organic matter (DOM): Effects of biological and photolytic degradation. Limnology and Oceanography, 61: 1015-1032. DOI: 10.1002/lno.10270

HAYES, M. H. B. \& R. S. SWIFT. 1978. The chemistry of soil organic colloids In: The chemistry of soil constituents. GREENLAND, D. J. E \& M. H. B. HAYES (ed.): 178-230. Wiley-Blackwell, Chichester. UK.

HAYES, M. H. B., R. S.SWIFT, C. M. BYRNE \& A. J. SIMPSON. 2010. The Isolation and Characterization of Humic Substances and Humin from Grey Brown Podzolic and Gley Grassland Soils. IUSS. Available at: http:// www.iuss.org/19th\%20WCSS/Symposium/ pdf/2343.pdf Acessed January, 2017.

IQDAL M. K., T. SHAFIQ, A. HUSSAIN \& K. AHMED. 2010. Effect of enrichment on chemical properties of MSW compost. Biore- 
source Technology, 101:5969-5977.

KLÜPFEL L., A. PIEPENBROCK, A. KAPPLER \& M. SANDER. 2014. Humic substances as fully regenerable electron acceptors in recurrently anoxic environments. Nature Geoscience, 7: 195-200. DOI: 10. 1038/NGEO2084

LI, X., B. CUI, Q. YANG, H. TIAN, Y. LAN, T. WANG \& Z. HANG. 2012. Detritus quality controls macrophyte decomposition under different nutrient concentrations in a eutrophic shallow lake, North China. Plos One, 7: e42042. DOI: 10.1371/journal.pone.0042042

LI, X., B. CUI, Q. YANG, T. LAN, T. WANG \& Z. HAN. 2013. Effects on plant species on macrophyte decomposition under three nutrient conditions in a eutrophic shallow lake, North China. Ecological Modelling, 252: 221-128. DOI: 10.1016/j.ecolmodel.2012.08. 006

LIU, S., T. ZHAO, Y. ZHU, X. QU, Z. HE, J. P. GIESY \& W. MENG. 2018. Molecular characterization of macrophyte-derived organic matters and their implications for lakes. Science of the Total Environment, 617:602-613. DOI: 10.1016/j.scitotenv.2017.10.289

MORAN, M. A. \& R. E. HODSON. 1989. Formation and bacterial utilization of dissolved organic carbon derived from detrital lignocellulose. Limnology and Oceanography, 62: 1034-1047.

OLK, D.C., P. R. BLOOM, M. DE NOBILI, Y. CHEN, D. M. MCKNIGHT, M. J. M. WELLS \& J. WEBER. 2019. Using humic fractions to understand natural organic matter processes in soil and water: selected studies and applications. Journal of Environmental Quality, 48: 1633-1643. DOI: 10.2134/jeq2019.03.0100

PAN, Y., X. ZHANG, K. SONG \& D. LIANGJUN. 2017. Applying trai-based method to investigate the relationship between macrophyte communities and environmental conditions in a eutrophic freshwater lake, China. Aquatic Botany, 142: 16-24. DOI: 10.1016/j. aquabot.2017.06.002

PÉREZ, J., J. MUÑOZ-DORADO, T. RUBIA \& J. MARTINEZ. 2002. Biodegradation and biological treatments of cellulose, hemicellulose and lignin: an overview. International
Journal of Microbiology, 5: 53-63.

PICCOLO A., A. COZZOLINO, P. CONTE \& R. SPACCINI. 2000. Polymerization of humic substances by an enzyme-catalyzed oxidative coupling. Naturwissenschaften, 87: 391-394. DOI: $10.1007 / \mathrm{s} 001140050747$

REJMÁNKOVÁ, E. \& K. HOUDKOVÁ. 2006. Wetland plant decomposition under different nutrient conditions: What is more important, litter quality or site quality? Biochemistry, 80:245-262.

ROCHA, R. J. S. 2012. Decomposição de macrófitas aquáticas em reservatórios com diferentes estados tróficos. Master Dissertation. Universidade Federal de São Carlos, Brazil.

ROCHA, R. J. S., M. B. CUNHA-SANTINO, J. A. MILAN \& I. BIANCHINI Jr. 2014. Total phosphorus determination in aquatic plants using an ignition method. Revista Tecnológica, 23: 69-74

RODEN E. E, A. KAPPLER, I. BAUER, J. JIANG, A. PAUL, R. STOESSER, H. KONISHI \& H. XU. 2010. Extracellular electron transfer through microbial reduction of solid-phase humic substances. Nature Geoscience, 3: 417-421. DOI: 10.1038/ngeo870

SCHELLEKENS, J., P. BUURMAN, K. KALBITZ, A. van ZOMEREN, P. VIDAL-TORRADO, C. CERLI \& R. N. J. COMANS. 2017. Molecular fatures of humic acids and fulvic acids from contrasting environments. Environmental Science and Technology, 51: 13301339. DOI: 10.1021/acs.est.6b03925

SCHNEIDER, B., E. R. CUNHA, M. MARCHESE \& S. M. THOMAZ. 2018. Association between macrophyte life forms and environment and morphometric factors in a large sub-tropical floodplain. Frontiers in Plant Science, 9. DOI: 10.3389/fpls.2018. 00195

SENESI N. 1989. Composted materials as organic fertilizers. The Science of the Total Environment, 81/82: 521-542.

SCOFILED, V., S. M. S. JACQUES, J. R. D. GUIMARÃES \& V. F. FARJALLA. 2015. Potential changes in bacterial metabolism associated with increase water temperature and nutrients input in tropical humic lagoons. Frontiers in Microbiology, 6: 1-10. DOI: 10. 
3389/fmicb.2015.00310

STEINBERG C. E. W., S. KAMARA, V. Y. PROKHOTSKAYA, L. MANUSADZIANAS, T. A. KARASYOVA, M. A. TIMOFEYEV, Z. JIE, A. PAUL, T. MEINELT, V. F. FARJALLA, A. Y. O. MATSUO, B. K. BURNISON \& R. MENZEL. 2006. Dissolved humic substances - Ecological driving forces from the individual to the ecosystem level. Freshwater Biology, 51: 1189-1210. DOI: 10.1111/j.1365-2427. 2006.01571.x

THURMAN E. M. 1985. Organic Geochemistry of Natural Waters. Dr W. Junk Publishers. Dordrecht. The Netherlands.

TRANVIK, L. J. 1988. Availability of dissolved organic carbon for planktonic bacteria in oligotrophic lakes of differing humic content. Microbial Ecology, 16: 311-322.

USELMAN, S. M., R. G. QUALLS \& J. LILIEN-
FEIN. 2012. Quality of soluble organic C, N, and $\mathrm{P}$ produced by different types and species of litter: root litter x leaf litter. Soil Biology and Biochemistry, 54: 57-67. DOI: 10.1016/j. soilbio.2012.03.021

VAN SOEST P. J. \& R. H. WINE. 1967. Use of detergents in the analysis of fibrous feeds. IV. Determination of plant cell wall constituents. Journal of Association of Official Analytical Chemists, 50: 50-55

WETZEL R. G. \& G. E. LIKENS. 1991. Limnological analyses. Springer. New York. USA. ZHANG D., C. ZHANG, Z. XIAO, D. SUZUKI \& A. KATAYAMA. 2015. Humin as an electron donor for enhancement of multiple microbial reduction reactions with different redox potentials in a consortium. Journal of Bioscience and Bioengineering, 119: 188-194. DOI: 10.1016/j.jbiosc.2014.07.010 